\title{
Social Networks as a Tool for Education: An Awareness of School Leaders
}

\author{
Nathara Mhunpiew, Joseph Purayidathil \\ Assumption University, Bangkok, Thailand
}

\begin{abstract}
By nature, every human being looks for knowledge and once he/she gets that, he/she shares it with others who are around him/her. So, it can be said that human beings are both information consumers and sharers. In the present world, social networks play an important role in human life. Studies reveal that human beings have adopted social media into their work, profession, and so on, other than just communication and entertainment. Education is one of the fields that adopted social media and new technologies to increase the course effectiveness. Social media can facilitate students in following professional societies, organizations, or faculty, as well as contributing discussion points or questions across a network. Nowadays, most of the schools have the technologies, but, if we analyze them, we will understand that they are presentational than interactive. This article gives a clear understanding about social networks and its use in the field of education, and concludes with some important points for the consideration of the school leaders for the use of social networks in the field of education by making use of all the potentials of social networks.
\end{abstract}

Keywords: social networks, tool for education, school leaders

\section{Introduction}

We are living in an era of social networks. A lot of possibilities are inherent in these social networks. While using different kinds of social networks in the daily life, we should understand the different possibilities that are inherent in them. Mostly, people around the world use these social networking sites for entertainment purpose. But nowadays, people started using them in other areas of life too, such as business, health, education, and so on. This article aims at those who are involved in the field of education in order to make them aware of the number of possibilities of the different social networking sites. This article has mainly three parts. The first part of it explains about social networks in general, the following part elaborates about how the different social networks are used as an educational tool, and the final part tries to explain about awareness that those in the field of education should have.

\section{Social Networks at a Glance}

Every human being by nature is a learner. He/she learns a lot of things from the environment where he/she lives and he/she makes use them for his/her survival. By nature, he/she is looking for information and he/she will search that from the available sources. This can be for addressing a problem or just to satisfy his/her

Nathara Mhunpiew, Ph.D., program director, Graduate School of Education, Assumption University.

Joseph Purayidathil, Ph.D. candidate, Graduate School of Education, Assumption University. 
curiosity. Once, he/she gets some information or knowledge, he/she shares that with the people around him/her. This common rule is applicable in the field of education, too. In the current situation, for information seeking, people make use of the technologies that are available and accessible for them. There is nothing wrong in saying that learners are both information consumers and information sharers. For consuming and sharing the information, the present generation uses social media or social networks. In other words, social media have become an integral part of the life of the present generation. Social media are redefining how individuals relate to each other as humans and how individuals as humans relate to the organizations that serve them. It is similar to a dialog which brings people together to discover and share information (Solis, 2008). Social media comprise of activities that involve socializing and networking online through words, pictures, and videos.

Social networking is one aspect of social media, where individuals are sharing ideas and interests, or are looking to meet people with similar ideas and interests in communities. "Social networking tools are among the most dominant on the Web today. These services bring people together with common interests, experiences, and activities; allowing people to share their commonalities” (Bonk, 2009, p. 329). Social networking sites assist people to chat, share files, discuss ideas, email each other, and so forth (Bonk, 2009). Social networking technologies help the users communicate and share their concepts on particular topics. In addition, these social networking sites are mainly used for social and entertainment purposes. They help individuals stay connected with their friends and the family members (Gustchmidt, 2012). Nowadays, social networks are becoming very popular and many are attracted to it. According to Al-Mukhaini, Al-Qayoudhi, and Al-Badi (2014), the proponents of social networking sites say that if you are not involved in social networking, then you are not alive.

At present, the most popular social networking communities include Facebook, Twitter, MySpace, LinkedIn, Google+, YouTube, and so on. The following paragraphs give a short description about the most popular and widely used social networks.

\section{Facebook}

Facebook is among the most popular social networking sites that are used for communication and it helps people stay connected with friends and others who work, study, and live around them. Facebook is made up of six primary components, such as personal profiles, status updates, networks (geographic regions, schools, and companies), groups, applications, and fan pages. People all over the world, regardless of their age level, are very keen to use Facebook for different purposes. A recent study conducted by Acquisti and Gross (2006) found out that students and teachers rely on Facebook in order to conduct classes and to attend sessions. This study also revealed that the students use Facebook in order to meet the professors and other students.

\section{Twitter}

"Twitter is a microblogging service that allows users to post and read 140-character status messages" (Ovadia, 2009, p. 202). In microblogging, it is one of the prominent social networking services. Its slogan to attract people to it is "the best way to discover what's new in your world” (Goroshko \& Samoilenko, 2011). Its users can also follow the updates of friends they "follow", send them direct messages, reply publicly to friends, or just post questions or comments as their current status (The New Media Consortium, 2007). Twitter helps teachers and students create their own learning network. It gives them the opportunity to find and connect with the lives of people around the world who can help them take their learning and teaching experience to the next level. 


\section{YouTube}

YouTube provides its users the facility to download or upload video files. At the same time, it allows its users to interact with others by making comments. This social networking tool helps its users search and find out the videos of their concern. Along with general users, those who are in the learning process can use YouTube videos to learn more about different topics by listening to lectures and classes of experts from different parts of the world.

\section{MySpace}

MySpace is an online community that lets you meet your friends' friends and share photos, journals, and interests. This site promotes social networking by giving access to built-in blogs and also allowing people to meet friends of friends and also interact with scholars throughout the world. Although it is most often used for simply chatting to friends and others, MySpace promotes and organizes many different political, economic, and artistic programming and endeavors that users may take part in. Studies reveal that people has adopted social media into their work, profession, education, and so on, other than just communication. Education is one of the fields that adopted social media and new technologies to increase the course effectiveness (Greenhow \& Robelia, 2009). At present, most of the colleges and universities are trying to adopt modern technologies to make communication with its stakeholders, both internal and external, which includes staff, students, parents, and community.

The above mentioned facts reveal that educational institutions started to use technology in the teaching and learning process. However, a genuine evaluation of the present educational systems makes it clear that existing educational systems fail to adopt the modern technologies and all the possible methods to help students learn. Studies revealed the fact that educational institutions are still primarily relying on traditional platforms of learning which do not help the learners manage and maintain their own learning space (McGloughlin \& Lee, 2010). People of all sorts of life are using the social media, which is a powerful and time-saving method to communicate and transfer their knowledge and thoughts. There is a lot of evidence that social media can support the learning activities, and it helps to share learning achievements and participate in collective knowledge creation or generation (Dabbagh \& Kitsantas, 2011).

There are a lot of universities using social networks as a tool for education all over the world. A study was conducted by Times in order to know the Top 10 universities which are using social networks in the year 2011-2012. According to the results of this study, the Top 10 are the following from first to last: Harvard University, University of Pennsylvania, Massachusetts Institute of Technology (MIT), University of Michigan, Stanford University, University of California, University of Oxford, University of Sheffield, University of Wisconsin, and University of Texas at Austin (Kelly, 2012).

In short, over the last five years, social networking sites, such as Facebook, MySpace, Twitter, and YouTube, have become household terms, but the use of social networking in education has seen little growth, especially considering its rapid rise elsewhere in society. Hence, by considering the relevance of adaptation of social networking in education, this article tries to make aware the leaners and teachers about the advantages of using social networking sites in the field of education.

\section{Social Media: A Tool for Education}

Given the interactive and collaborative nature that defines social networking, there is tremendous potential 
for the field of education. Colleges and universities are beginning to embrace social media and realizing the potential power and implications for using it in education. Typically, educational institutions are taking action by providing suitable materials in classrooms, labs, and lecture halls. Liccardi et al., (2007) suggested that many of the existing educational activities that are done face-to-face, such as peer assessment, discussions, and collaborative works, can be replaced with the help of social networking sites. Previous research has been documented that educational activities which include interaction, collaboration, critical thinking, active participation, information seeking, resource sharing, and so on, can be supported by social networking tools (Mazman \& Usluel, 2010). Similarly, Blankenship (2010) stated that the use of social networking tools in education results in many benefits, such as greater student engagement, greater student interest, students taking more control over their education, and more responsibility for their education. Studies also show that social networking tools support educational activities by making interaction, collaboration, and active participation.

At present, a lot of educational institutions are making use of the advantages of social networks in the teaching and learning process. According to the results of the study conducted by the U.S. Department of Education (2009), the classes using social networks or online systems were found to be more effective than the classes using the traditional face-to-face instruction. A study conducted by the Educause Center for Applied Research revealed the fact that there was a big increase in the use of social media by the students (Smith \& Caruso, 2010). This study showed that there was a steady growth in the use of social media from 2007 to 2010. The results of this study revealed the fact that the students were integrating the social media in their studies both formally and informally. Furthermore, the faculty also encourage the students to use the social networks in their teaching and learning process. This study also revealed that social media help the staff and students to be more collaborative and active.

The new generation students can be also called the "Net generation" or the "conceptual age" (Gustchmidt, 2012). This study also revealed the fact that the new generation students made use of the technologies to think, to collaborate, and to create. Another study by Jacquemin, Smelser, and Bernot (2014) revealed that the students used social media more frequently than the faculty. Besides that, the study also found that the students identified with the positive aspects of social media inclusion into their courses than the faculty members. There can be many reasons for these differences in the use of social media.

Revere and Kovach (2011) mentioned in their study that social media and online contents provide a continuous stream of information better suited for "always on" students. Social media can facilitate students in following professional societies, organizations, or faculty, as well as contributing discussion points or questions across a network. All the studies that are mentioned earlier suggest that social media, nowadays, are used as a tool for developing or increasing formal or informal learning experiences, which stands as a personal learning environment, enabling individual knowledge management.

Computer is a viable educational tool which has the ability to bring about positive changes to the classrooms and schools in general (Albirini, 2006). The contemporary students are not learning things as the former generations did. So, it is necessary to make use of the new ways and to change the old patterns of teaching that belong to the traditional methods of classroom teaching. In most of the educational institutions, the technologies are provided for the students, but the problem there is that most of those technologies are presentational rather than interactive. In most of the schools or higher education institutions, some universities or colleges have put filters on the computers so that the students and the faculty cannot go to some sites. They 
are restricted by the school administrators. The true fact is that there is a disparity between the technologies that the students use for recreation and those use for education purpose. If students are prohibited to use the social networking sites, there will not be many improvements in their academic outcomes.

In education, communication between the lecturer and the student is a key part of student success. Students are among the largest demographic of people using social networking to communicate. The use of social networks is a growing phenomenon in both private and academic life. Social networks refer to tools used to enable users for social interaction. The use of social networks complements and enhances teaching in traditional classrooms. Bonk (2009) stated that "During the past few years, Facebook has become highly popular among college professors and other academic professionals” (p. 329). In addition,YouTube, Wikis, and blogs provide a huge amount of material on a wide range of subjects and hence, at any time, learners depend on some of these social networking sites for clarifying their doubts. Besides these, social networking sites assist students to get answers for their questions from the teachers or friends by posting the questions into networking sites. When the students post their doubts in the special forum of the networking sites, teachers or classmates will get the chance to answer them.

Moreover, the use of social media for teachers and students, as a medium of communication, could make the process of advice, support, and instruction more transparent and simpler. Instead of traditional "office hours", students and lecturers could openly communicate on social networks with the use of common, course-specific terms for indexing on Twitter, or a course-specific group on another social network without the traditional barriers of time and space. Social networking can be used to "showcase" work done by students and faculty, or to invite comment upon research as well as efficiently and effectively gather data for research. Instead of creating distance between students and lecturers, it has the potential to create closer and stronger relationships (M. Thomas \& H. Thomas, 2012).

\section{An Awareness of School Leaders}

As mentioned above, social networking sites play an important role in today's educational system. Social networking promises to be a powerful educational tool that allows students to collaborate and share information as never before. As educationalists, keeping up to date with instructional methods that could enhance and expand learning opportunities for students is of great importance in the ever-changing global landscape. Since education is a competitive area now, it is the duty of school administrators to take necessary steps that are demanded by the time. The management or the administrators should arrange some experts in the area of social networks to clear the doubts of the students and to facilitate them with the knowledge how to use social networks effectively in their learning activities. This will help the students save both their time and money by doing interactions through the Internet than meetings in a particular place. While doing the exchange of papers and submission of projects and assignments through the Internet, they can save the printing cost. At present, most universities and colleges urge their students to submit their assignments and papers online. While encouraging the students to do so, the management should make sure that the way how to do this is clear for the students and the faculty.

The close observation of the university, school, and college campuses will reveal that students are always moving around and using electronic gadgets that they have. They are equipped with the modern technological devices like iPhones, tablets, notebooks, and so on. Leaders in the educational field should realize the fact that what they need to do in their institutions is just helping the students make use those things in their education 
and knowledge acquiring process, because there are lot of social networks that can help students and teachers to engage into active discussions on different topics that they study and teach. This will help the staff and students think more and share their views and understandings by using social networks.

This article should urge and motivate the minds of educational leaders and administrators to help teachers and students access social media as much as possible, in order to promote and provide the facilities for them to use in the teaching and learning process. This article should urge the leaders to think about that:

1. Opportunities should be provided to students and teachers to have sufficient knowledge for the positive use of social media and the access to them in the campuses. For this, school leaders should make use of the knowledge and time of the external experts in this field;

2. The use of social media among the staff and students should be assessed by making use of the help of the information technology professionals;

3. Perception of staff and students towards social media should be evaluated by conducting timely research;

4. The fact that social networks have the potential to be both constructive and destructive in the classroom context should be reminded;

5. Teachers should be aware of the fact that there are many social networks that can really help in education. They should know the pros and cons of social networks before they are used as a tool for education. They can improve their knowledge in this area from experts' advice, books, articles, and so on;

6. The venue to improve the knowledge of both teachers and students should be provided by trainings through workshops, seminars, and so on, before implementing the new system.

The above stated six points are some key points that educational leaders should have in their mind when implementing social networks as a tool for education. It should be kept in mind that social networks are very good tools for education if used prudently and wisely. Otherwise, it will have negative effects on the users. So, this article gives the readers awareness on the prudent use of social networks. Social networks have the potential to be both constructive and destructive. It is we who decide how to use it.

\section{Conclusion}

This article is presented in three parts. The first part of it explains in detail about the importance of social networks in the current world where we are living. This part explains about the most widely used social networks, too. The following section of the article elaborates about how social networks can be used as a tool for the education. The use of social networks in the educational field results in greater student engagement, greater student interest, students taking more control over their education, and more responsibility for their education. The results of many studies also show that social networking tools support educational activities by making interaction, collaboration, and active participation. Social networks are used for communication and interaction among people from different parts of the world. This part explains how social networks help the interaction between teachers and students in the educational context. The final part of the article helps school leaders and those in the educational field to understand the important points that they have to consider while they start implementing social networks in their schools, colleges, and universities. Social networks can be used successfully in the context of education because they have got tremendous power. What we have to do is to understand and help students understand to make use of those possibilities. 


\section{References}

Acquisti, A., \& Gross, R. (2006, January). Imagined communities: Awareness, information sharing, and privacy on the Facebook. In Privacy enhancing technologies (pp. 36-58). Heidelberg, Berlin: Springer.

Albirini, A. (2006). Teachers' attitudes toward information and communication technologies: The case of Syrian EFL teachers. Computers \& Education, 47(4), 373-398.

Al-Mukhaini, E. M., Al-Qayoudhi, W. S., \& Al-Badi, A. H. (2014). Adoption of social networking in education: A study of the use of social networks by higher education students in Oman. Journal of International Education Research, 10(2), 143-154.

Blankenship, M. (2010). How social media can and should impact higher education. Hispanic Outlook, pp. 11-12.

Bonk, C. J. (2009). The world is open, how Web technology is revolutionizing education. San Francisco, C.A.: Jossey-Bass.

Dabbagh, N., \& Kitsantas, A. (2011). Personal learning environments, social media, and self-regulated learning: A natural formula for connecting formal and informal learning. Internet and Higher Education, 15(1), 3-8.

Goroshko, O. I., \& Samoilenko, S. A. (2011). Twitter as a conversation through e-learning context. Revista de Informatica Sociala, VIII, 15.

Greenhow, C., \& Robelia, B. (2009). Old communication, new literacies: Social network sites as social learning resources. Journal of Computer-Mediated Communication, 14, 1130-1161.

Gustchmidt, A. M. (2012). A case study investigating the use of Facebook as a learning management system in higher education. (Doctoral dissertation, North Carolina State University).

Jacquemin, S. J., Smelser, L. K., \& Bernot, M. J. (2014). Twitter in the higher education classroom: A student and faculty assessment of use and perception. Journal of College Science Teaching, 43(6), 2-9.

Kelly, S. M. (2012). Top 10 social media-savvy universities. Retrieved from http://mashable. com/2012/03/30/universities-socialmedia-savvy/

Liccardi, I., Ounnas, A., Pau, R., Massey, E., Kinnunen, P., Lewthwaite, S., ... Sarkar, C. (2007). The role of social networks in students’ learning experiences. Proceeding of ACM SIGCSE Bulletin, 39, 224-237.

Mazman, S. G., \& Usluel, Y. K. (2010). Modeling educational usage of Facebook. Computers \& Education, 55(2), 444-453.

McGloughlin, C., \& Lee, M. J. W. (2010). Personalised and self regulated learning in the Web 2.0 era: International exemplars of innovative pedagogy using social software. Australasian Journal of Educational Technology, 26(1), 28-43.

Ovadia, S. (2009). Exploring the potential of Twitter as a research tool. Behavioral \& Social Sciences Librarian, 28(4), 202-205.

Qualman, E. (2010). Socialnomics (Video). Retrieved November 5, 2014, from http://www.youtube.com/watch? vQzZyUaQv pdc

Revere, L., \& Kovach, J. V. (2011). Online technologies for engaged learning: A meaningful synthesis for educators. Quarterly Review of Distance Education, 12, 113-124.

Smith, S. D., \& Caruso, J. B. (2010). The ECAR study of undergraduate students and information technology (p. 118). Colorado: Educause Center for Aplied Research.

Solis, B. (2008). Customer service: The art of listening and engagement through social media: 32. Retrieved November 17, 2014, from http://www.ciff.net/seminarioformanciononline/DocumentoSeminarioII.pdf

Tham, C. M., \& Werner, J. M. (2005). Designing and evaluating e-learning in higher education: A review and recommendations. Journal of Leadership \& Organizational Studies, 11(2), 15-25.

The New Media Consortium. (2007). Social networking, the "third place”, and the evolution of communication (The New Media Consortium White Paper).

Thomas, M., \& Thomas, H. (2012). Using new social media and Web 2.0 technologies in business school teaching and learning. Journal of Management Development, 31(4), 358-367.

U.S. Department of Education. (2009). Evaluation of evidence-based practices in online learning: A meta-analysis and review of online learning studies. Washington, D.C.: U.S. Department of Education, Office of Planning, Evaluation, and Policy Development. 